\title{
Productidinid brachiopods (Strophomenata, Productida), including Martinezchaconia luisae new genus and new species of Linoproductidae, from the Carboniferous of Santiago Ixtaltepec region, Oaxaca, Southeast México
}

\author{
Miguel A. TORRES-MARTÍNEZ \& Francisco SOUR-TOVAR ${ }^{2 *}$
}

\author{
${ }^{1}$ Instituto de Geología, Departamento de Paleontología, Universidad Nacional Autónoma de México, Ciudad Universitaria, \\ Ciudad de México, 04510, México; miguelatm@geologia.unam.mx \\ ${ }^{2}$ Museo de Paleontología, Departamento de Biología Evolutiva, Facultad de Ciencias, Universidad Nacional Autónoma de \\ México, Ciudad Universitaria, Ciudad de México,04510, México; fcosour@ciencias.unam.mx \\ * Corresponding author
}

Torres-Martínez, M.A. \& Sour-Tovar, F. 2018. Productidinid brachiopods (Strophomenata, Productida), including Martinezchaconia luisae new genus and new species of Linoproductidae, from the Carboniferous of Santiago Ixtaltepec region, Oaxaca, Southeast México. [Braquiópodos productinidos (Strophomenata, Productida), incluyendo a Martinezchaconia luisae nuevo género y especie de Linoproductidae, del Carbonífero de la región de Santiago Ixtaltepec, Oaxaca, Sur de México]. Spanish Journal of Palaeontology, 33 (1), 205-214.

\begin{abstract}
We describe three brachiopod species of the Suborder Productidina from the Ixtaltepec Formation, Carboniferous of the north of Oaxaca State, southern Mexico, found in perireef deposits. Stegacanthia bowsheri and Undaria sp. are members of the families Sentosiidae and Monticuliferidae respectively and were found in strata of the Visean (Middle Mississippian). Martinezchaconia luisae, new genus and species of the Family Linoproductidae, was recollected in Bashkirian-Moscovian (Lower-Middle Pennsylvanian) strata. The respective ages are inferred from the index species of brachiopods associated with the productidines herein described.
\end{abstract}

Keywords: Brachiopods, Productidina, Carboniferous, Mexico.

\section{RESUMEN}

Se describen tres especies de braquiópodos del Suborden Productidina que se encontraron en rocas carboníferas, depositadas en ambientes peri-arrecifales de la Formación Ixtaltepec en el norte del Estado de Oaxaca, Sur de México. Stegacanthia bowsheri y Undaria sp., son representantes de las familias Sentosiidae y Monticuliferidae respectivamente, proceden de estratos del Viséense (Misisípico Medio). Martinezchaconia luisae, nuevo género y especie de la Familia Linoproductidae, se encontró en estratos del Bashkiriense-Moscoviense (Pensilvánico Inferior-Medio). Las respectivas edades se infieren a partir de especies índice de braquiópodos que se encuentran asociadas y que han sido referidas previamente para los estratos fosilíferos estudiados.

Palabras clave: Braquiópodos, Productidina, Carbonífero, México. 


\section{INTRODUCTION}

In 1970, the Mexican geologist J. Pantoja-Alor reported the presence of Cambrian-Ordovician and Carboniferous outcrops in the region of Asunción Nochixtlán, north of Oaxaca state, southern México. Since that year, several publications have been generated describing the Paleozoic marine fauna of the region, which is characterized by its great abundance and diversity of invertebrates. Examples of such publications are those related with the Carboniferous material, such as the description of bryozoans (GonzálezMora \& Sour-Tovar, 2014), brachiopods (Navarro-Santillán et al., 2002; Sour-Tovar \& Martínez-Chacón, 2004; TorresMartínez et al., 2008; Torres-Martínez \& Sour-Tovar, 2012, 2016a, 2016b), bivalves (Quiroz-Barroso \& Perrilliat, 1997, 1998), trilobites (Morón-Ríos \& Perrilliat, 1988) and crinoids (Villanueva-Olea et al., 2011; Villanueva-Olea \& Sour-Tovar, 2015).

Brachiopods are the most abundant and diverse group at all stratigraphic levels of Carboniferous age from northern Oaxaca State. The works that have been published on them suggest strong paleobiogeographical affinities with North American coal faunas, over those found in the MidContinent region, but the presence of endemic genera and species is remarkable. In particular, brachiopods of the Order Productida are the most common taxa and many of their suborders are well represented. The present work reports the presence of three species of the Suborder Productidina, which had never been recorded in the Carboniferous outcrops of the State of Oaxaca.

\section{GEOLOGICAL SETTING AND AGES}

The Carboniferous outcrops are located in the Santiago Ixtaltepec region, which occurs to $19 \mathrm{~km}$ northwest of the city of Asunción Nochixtlán, Oaxaca State in southern Mexico. The specimens described in this work were collected in the type section Arroyo de las Pulgas of the Ixtaltepec Formation (Pantoja-Alor, 1970), located to 500 $m$ north of Santiago Ixtaltepec town, between 17 $32^{\prime}$ and $17^{\circ} 33^{\prime}$ latitude $\mathrm{N}$ and $97^{\circ} 06^{\prime}$ and $97^{\circ} 07^{\prime}$ longitude W (Fig. 1).

In the region of Santiago Ixtaltepec is possible to observe the Oaxacan Complex, a basement composed of Proterozoic pegmatites, schist, paragneiss and orthogneiss with ages of 900-1100 million years (Fries et al., 1962; Solari et al., 2003). Overlaying the Precambrian basement is the Tiñú Formation (Robison \& PantojaAlor, 1968), a Cambrian-Ordovician succession of calcareous and argillaceous rocks with abundant trilobites and other invertebrate fossils (Robison \& Pantoja-Alor, 1968; Landing et al., 2007, 2010). The Carboniferous succession begins on top of the Tiñú Formation and was originally divided into two formations (PantojaAlor, 1970; Navarro-Santillán et al., 2002). The lower formation is the Santiago Formation, an informal unit by homonymy that was considered as Mississippian. The upper one is the Ixtaltepec Formation, Late Mississippian and Pennsylvanian in age. Santiago Formation is $165 \mathrm{~m}$ thick and unconformably overlies the Tiñú Formation (Cambrian-Ordovician). It has been informally divided

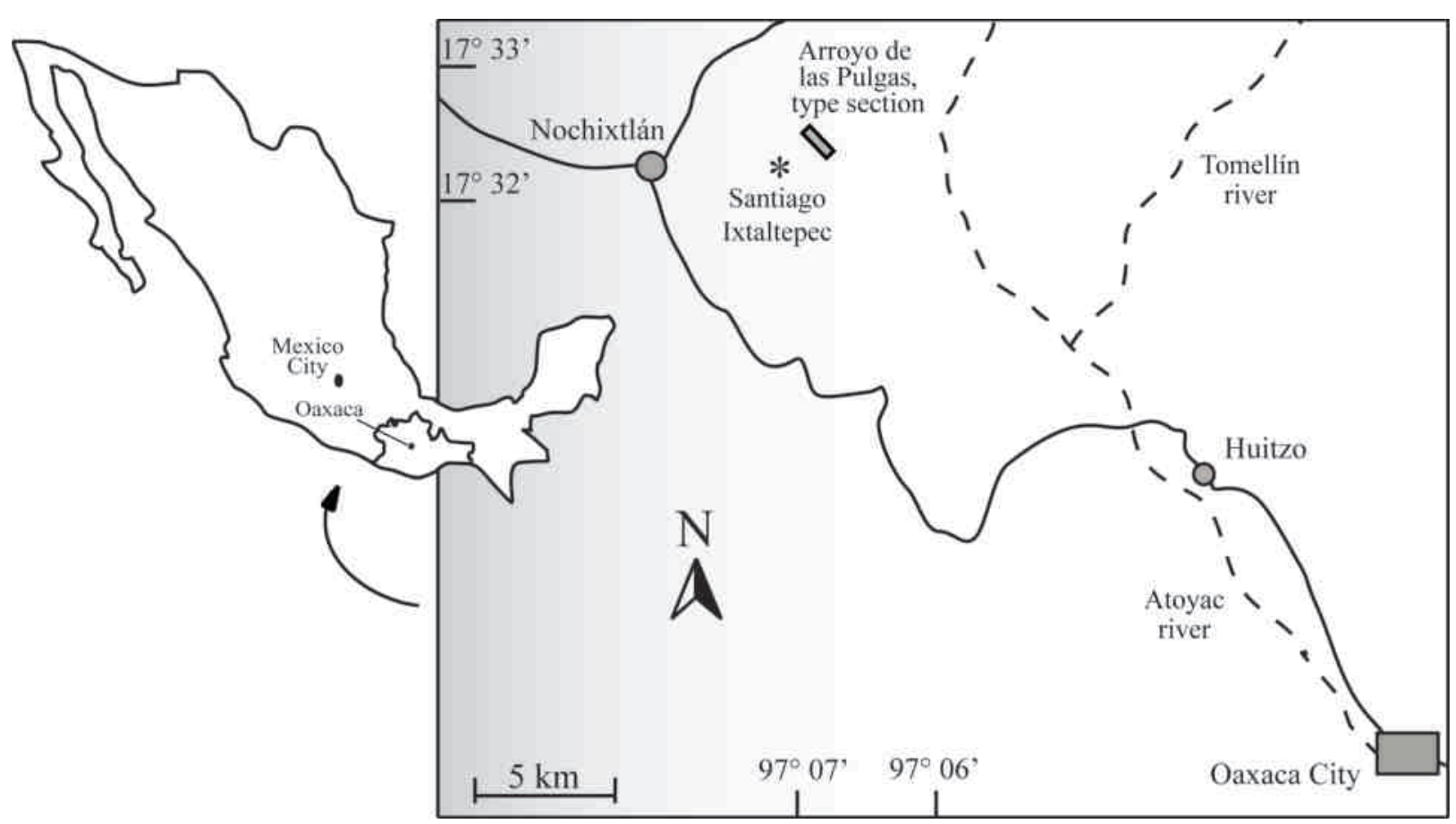

Figure 1. Geographic location of the Ixtaltepec Formation, Arroyo de las Pulgas type section. 
into two members. The Lower Member consists of $65 \mathrm{~m}$ of sandstone, limestone and calcareous sandstone containing abundant fossils of invertebrates of the Early Mississippian (Tournaisian) (Quiroz-Barroso et al., 2000; NavarroSantillán et al., 2002). The Upper Member is composed of approximately $100 \mathrm{~m}$ of shale and fine-grained sandstone, including Middle Mississippian cephalopods (CastilloEspinoza, 2013).

The Ixtaltepec Formation is $430 \mathrm{~m}$ thick at the type section Arroyo de las Pulgas, where conformably overlies the Santiago Formation. The basal part includes $90 \mathrm{~m}$ of interbedded siltstone, sandstone, sandy limestone and shale. The rest of the Ixtaltepec Formation is mainly made up of shale and minor fine-grained sandstone. Eight fossiliferous intervals, from the base to the top (API-1 to API-8), have been recognized in this formation (Fig. 2), each one characterized by its own fossil association. The productidinid brachiopods described in the present work were collected in the units API-2 (Stegacanthia bowsheri and Undaria sp.) and API-7 (Martinezchaconia luisae). Unit API-2 is characterized by the presence of different brachiopods (Torres-Martínez \& Sour-Tovar, 2012, 2016a, 2016b), bivalves (Quiroz-Barroso \& Perrilliat, 1997, 1998), crinoids (Villanueva-Olea \& Sour-Tovar, 2015) and other groups of invertebrates not formally described to date. Among the brachiopods that have been referred for this unit, the species Ovatia muralis (Torres-Martínez \& Sour-Tovar, 2012), Inflatia inflata (Torres-Martínez \& Sour-Tovar, 2016b) and Orbiculoidea caneyana (TorresMartínez \& Sour-Tovar, 2016a), allowed assigning the Unit API-2 to the Visean (Middle Mississippian).

In the Unit API-7, the brachiopods Neochonetes $(N)$ granulifer (Sour-Tovar \& Martínez-Chacón, 2004), Echinaria knighti, Linoproductus platyumbonus, Linoproductus prattenianus (Torres-Martínez \& SourTovar, 2012), Orbiculoidea missouriensis, O. capuliformis (Torres-Martínez \& Sour-Tovar, 2016a) and Reticulatia huecoensis, (Torres-Martínez \& Sour-Tovar, 2016b) suggest a Bashkirian-Moscovian (Early-Middle Pennsylvanian) age and allow to assign the new genus herein described to this interval of time. It has been inferred that the deposition of sediments of the Ixtaltepec Formation occurred in a shallow sea that, over time, underwent variations in depth, energy and input of types of sediments developing intertidal, reef or peri-reef sub-environments (GonzálezMora \& Sour-Tovar, 2014; Torres-Martínez \& Sour Tovar, 2016a). In particular, the Units API-2 and API-7 are characterized by the dominance of fine strata of shale and limonite with few lenses of carbonates. In both units, it has been inferred that they were deposited in a peri-reef environment.

Unconformably overlaying the Ixtaltepec Formation is the Yododeñe Formation, a conglomerate of Permian to Jurassic age. In the study region, Cretaceous calcareous rocks cover the Paleozoic outcrops. Figure 2 shows the stratigraphic column of the Santiago Ixtaltepec region, the relationship between the different units that have been recognized and the location of the stratigraphic units in which brachiopods described were collected.

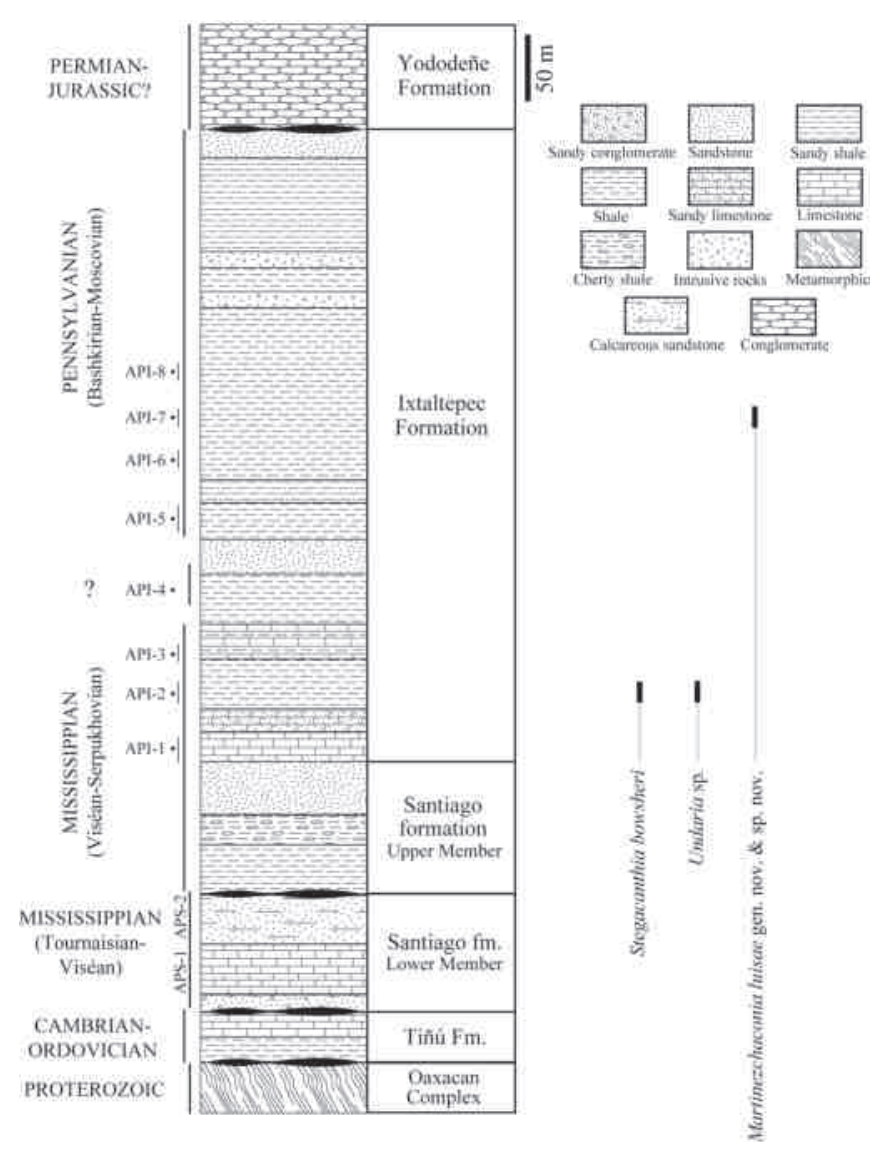

Figure 2. Stratigraphic column of the Santiago Ixtaltepec region. It shows the relationship between the different units that have been recognized and the location of the stratigraphic units in which brachiopods described were collected.

\section{SYSTEMATIC PALAEONTOLOGY}

All specimens studied are deposited at the Museo de Paleontología, Facultad de Ciencias, Universidad Nacional Autónoma de México. Type and figured specimens are designated in the descriptions by the prefix FCMP. The material is preserved as internal and external molds of both valves. In many cases, the internal molds of ventral valves are composite molds where it is just possible to see the external morphology. The description is based on the terminology of Brunton et al. (2000).

Phylum BRACHIOPODA Duméril, 1805

Subphylum RHYNCHONELLIFORMEA Williams, Carlson, Brunton, Holmer \& Popov, 1996 
Class STROPHOMENATA Williams, Carlson,

Brunton, Holmer \& Popov, 1996

Order PRODUCTIDA Sarytcheva \& Sokolskaya, 1959

Suborder PRODUCTIDINA Waagen, 1883

Superfamily Echinoconchoidea Stehli, 1954

Family Sentosiidae McKellar, 1970

Subfamily Sentosiinae McKellar, 1970

Tribe Sentosiini McKellar, 1970

Genus Stegacanthia Muir-Wood \& Cooper, 1960

Type species Stegacanthia bowsheri Muir-Wood \& Cooper, 1960 (New Mexico, United States. Upper Visean).

Stegacanthia bowsheri, Muir-Wood \& Cooper, 1960 (Figs 3a-b)

1960 Stegacanthia bowsheri Muir-Wood \& Cooper, p. 199, 200, pl. 48, figs 1-12.

1968 Stegacanthia aff. bowsheri, Carter, p. 1141.

1987 Stegacanthia cf. bowsheri, Carter, p. 33, pl. 11, figs 7-12.

2005 Stegacanthia bowsheri, Shi et al., p. 47, pl. 3I-J, 7.

2014 Stegacanthia bowsheri, Carter et al., p. 273, figs $7 \mathrm{~N}-\mathrm{P}$.

Occurrence. The specimen described is from Ixtaltepec Formation, Arroyo de las Pulgas type section, level API2, Visean (Middle Mississippian).

Material. A composite mold; a ventral external mold with part of dorsal internal and external molds (FCMP 1200).

Description. Medium-sized concavo-convex shell, subpentagonal in outline with greatest width at midlength. The specimen described is incomplete with approximately $16 \mathrm{~mm}$ in length and $25 \mathrm{~mm}$ in width. Ventral valve slightly convex, not geniculate, most inflated in posterior region. Sulcus moderately deep. Flanks spread. Strongly curved acute umbo on the hingeline with beak small. Hinge smaller than the greatest width. Short ears. Surface ornamented by lamellose bands, which are more width at the posterior half of the valve, overlapping next anterior band. Spines in concentric rows above the bands, seven occurring in a space of $5 \mathrm{~mm}$ at midlength. Dorsal valve slightly concave with low fold, similar ornament to ventral valve but narrower bands and smaller spines. Interior with externally bilobate cardinal process. Median septum low, reaches a larger size than midlength. Subtrigonal and dendritic adductor scars.
Remarks. Ixtaltepec specimen resembles Stegacanthia bowsheri material from the Lake Valley Formation (Upper Mississippian) of New Mexico, described by Muir-Wood \& Cooper (1960, p. 199, figs. 1-12). Traits as the nongeniculated ventral valve, umbo incurved on the hingeline, hinge smaller than the greatest width, short ears, lamellose bands of irregular width which overlapping next anterior band, lamellae ornamented of spines in concentric rows above bands, 14 occurring in a space of $10 \mathrm{~mm}$ and a dorsal valve slightly concave with narrower bands and smaller spines allowed relating the specimen herein described with those reported in New Mexico. This species has been recorded in the Mississippian of New Mexico (Muir-Wood \& Cooper, 1960), Missouri (Carter, 1968) and Arizona (Carter et al., 2014) in the United States, as well as in Canada (Carter, 1987) and China (Shi et al., 2005). This is the first occurrence of $S$. bowsheri in Mexico.

Superfamily Linoproductoidea Stehli, 1954

Family Linoproductidae Stehli, 1954

Subfamily Anidanthinae Waterhouse, 1968

Genus Martinezchaconia Torres-Martínez \& SourTovar gen. nov.

Type species Martinezchaconia luisae TorresMartínez \& Sour-Tovar sp. nov.

Diagnosis. Ventral valve with greatest convexity at midlength, geniculated, short trail. Sulcus extending from the beak until the anterior margin. Ears well-differentiated subquadrate to subtriangular, separated from umbonal slopes by a shallow concave flexure. The ornamentation consists of low costae, begins on the beak and extends to end of trail, absent on ears. Narrow and irregular rugae on the entire valve. Spines on ears, occurring in single row parallel to hinge. Dorsal valve with weak median fold. Ornament is similar to the ventral valve, without spines. Interior with fine median septum, extended forward about two-thirds of the length of the valve. Small cardinal process, posteriorly bilobate and anteriorly tetralobate. Lateral ridges diverge slightly from the hinge, reaching the midlength of ears. Adductor scars dendritic, posterior and anterior no differenced. Small endospines anterior of the visceral disc.

Etymology. In recognition of Dr. María Luisa Martínez Chacón, by her academic work and contributions on the palaeontology of invertebrates, particularly of brachiopods.

Occurrence. The specimens described are from Ixtaltepec Formation, Arroyo de las Pulgas type section, level API-7, Bashkirian-Moscovian (Lower-Middle Pennsylvanian). 
Remarks. The genus described is assigned to the subfamily Anidanthinae based on shape of ears, concentric lamellae on both valves and deep corpus cavity (Brunton et al., 2000). Although the description of the subfamily Anidanthinae by Brunton et al. (2000) includes welldeveloped ears as a distinctive character, not all the genera included in this group share this morphologic feature. Only Akatchania, Kuvelousia and Zia display well-differentiated ears, a trait also present in the new genus Martinezchaconia. Mexican specimens have certain structural similarities with other taxa within the subfamily. However, they do not belong to any of the previously described genera. Martinezchaconia resembles Anidanthus Hill, 1950 (upper early Permian-lower late Permian of Australia, northern and central Asia and central America), due to the presence of spines in row near hinge, absence of costae on ears and dorsal lamellae. However, Anidanthus shows different transverse shape in outline, large ears, spines widely scattered on corpus, and median septum about half disk length. Akatchania Klets in Abramov \& Grigorjeva, 1988 (early Permian $=$ Asselian of central Siberia) differs from Martinezchaconia by its shallow cavity, hinge width approximately equal to corpus width, widely separated lamellae, short median septum, and complete lateral ridges in both valves. Fusiproductus Waterhouse, 1975 (late Permian = Capitanian of China, ?Urals and ?Siberia) is different from Martinezchaconia by its smaller size, highly enrolled ventral valve, wide outline with large subtubular ventral ears, and single spines on ears. Kuvelousia Waterhouse, 1968 (late Permian = Kazanian of Arctic Canada, USA and eastern Australia) is distinguished from Martinezchaconia by its larger size, widely scattered spines on ventral valve, thicker dorsal valve, and larger median septum. Megousia Muir-Wood \& Cooper, 1960 (lower late Permian of North America, eastern Australia and Tasmania) differs from the new genus by its transverse shape, spines scattered on ventral valve, costae on ears, and extended ears curving anterodorsally. Protanidanthus Liao, 1979 (early Permian of China) is different from Martinezchaconia by its transverse shape, widely scattered spines on ventral valve, large ears, more convex ventral valve, and lack of dorsal lamellae. Zia Sutherland \& Harlow, 1973 (late Carboniferous = Bashkirian-early Permian $=$ Asselian of southern USA) differs from Martinezchaconia in its subcircular shape, flattened ventral disk, scattered spines on ventral valve, divergent lateral ridges into ear baffles, and smaller median septum. Mongousia Manankov, 2008 (late Permian of Mongolia) can be distinguished from Martinezchaconia by its transverse shape, large trail, strongly pronounced and stretched ears with their ends crescent-like curved, thin spines scattered on ventral valve, and well-pronounced and divided adductor scars. Nuanducosia Torres-Martínez \& Sour-Tovar, 2012 (late Carboniferous = Moscovian of
Mexico) differs from the new genus in the larger size, transverse shape, large ears, spines on trail and ears, and trilobate cardinal process.

\section{Martinezchaconia luisae Torres-Martínez \& Sour-Tovar} sp. nov.

(Figs 3c-j)

Etymology. Like for the genus.

Types. A ventral internal mold (FCMP 1201) (holotype), two ventral external molds (FCMP 1202, 1203), four dorsal external molds (FCMP 1204, 1205, 1206, 1207) and two dorsal internal molds (FCMP 1208, 1209).

Occurrence. The specimens described are from Ixtaltepec Formation, Arroyo de las Pulgas type section, level API-7, Bashkirian-Moscovian (Lower-Middle Pennsylvanian).

Diagnosis. Ventral valve with sulcus posteriorly narrow, extending from the beak until the anterior edge. The acute beak slightly overhanging hinge. Ears welldifferentiated, slightly arched. Surface ornamented by subequal costae, 12 to 16 occur in a space of $10 \mathrm{~mm}$ at anterior margin, separated by slightly narrower intercostal furrows, bifurcation starting at visceral disc, interrupted and enlarged by rugae. Discontinuous rugae on the valve, more notorious on flanks and ears. Four spines occurring on each ear. Dorsal valve slightly concave, principally on visceral disc. Concentric lamellae are notorious on the entire valve. Interior with long median septum. Small cardinal process, posteriorly bilobate. Lateral ridges short, reach the midlength of ears. Adductor scars are elongated and subtrigonal. Six to eight concentric rows of small endospines in front of the visceral disc.

Description. Shell moderate-sized for the subfamily, concavo-convex, subquadrate in outline, greatest width at hingeline. Deep corpus cavity. Ventral valve slightly convex with greatest convexity at midlength, geniculated, short trail. Sulcus posteriorly narrow, extending from the beak until the anterior edge. Narrow umbo, the acute beak slightly overhanging hinge. Ears well differentiated, slightly arched, subquadrate to subtriangular, separated from umbonal slopes by a shallow concave flexure. Ornamented by subequal low costae, 12 to 16 per 10 $\mathrm{mm}$ at anterior margin which begin on the beak and extend to end of trail, separated by slightly narrower intercostal furrows, absent on ears, bifurcation starting at visceral disc, interrupted and enlarged by rugae. Narrow, discontinuous, and irregular rugae on the valve, more notorious on flanks and ears. Four spines occurring on each ear, in single row parallel to hinge. Ventral interior not observed. Dorsal valve slightly concave, principally on 


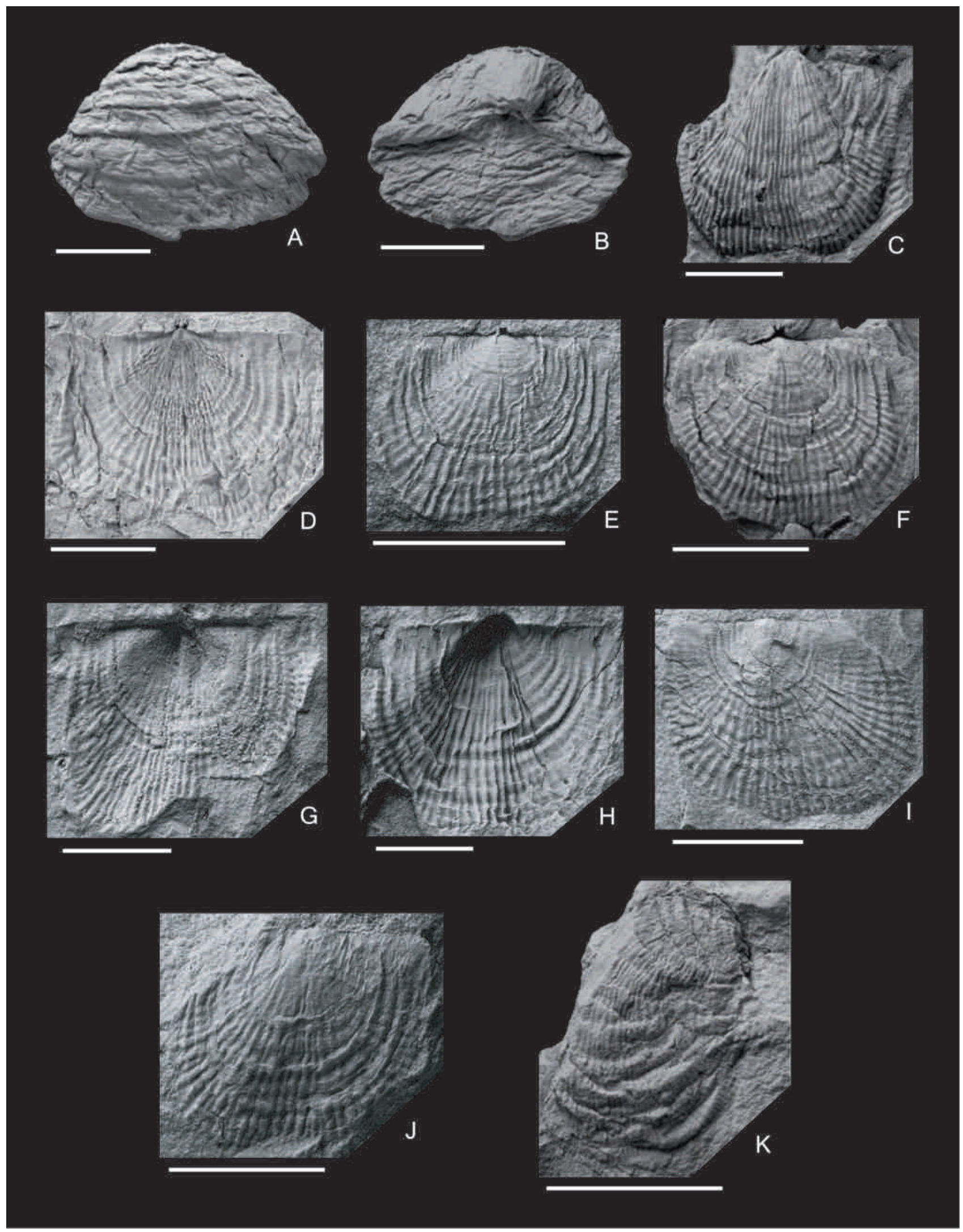

Figure 3. a, b) Stegacanthia bowsheri Muir-Wood \& Cooper. FCMP 1200, composite mold in ventral (a) and dorsal view (b). c-j) Martinezchaconia luisae Torres-Martínez \& Sour-Tovar. c) FCMP 1201, holotype, ventral internal mold. (d) FCMP 1209, dorsal internal mold. (e) FCMP 1207, dorsal external mold. (f) FCMP 1205, dorsal external mold. (g) FCMP 1208, dorsal internal mold. (h) FCMP 1202, ventral external mold. (i) FCMP 1206, dorsal external mold. (j) FCMP 1204, dorsal external mold. k) Undaria sp. FCMP 1210, ventral valve. Scale bars $=1.0 \mathrm{~cm}$. 
visceral disc. Gentle median fold, corresponding to sulcus of ventral valve. Short ears, separated from umbonal slopes by a weak concave flexure. Ornament is similar to the ventral valve, but concentric lamellae are more notorious on the entire valve. Spines not observed and presumably absent. Interior with fine median septum, long, extended forward about two-thirds of the length of the valve. Small cardinal process, short, posteriorly bilobate and anteriorly tetralobate. Lateral ridges short and are slightly divergent from the hinge, reaching the midlength of ears. Adductor scars are dendritic, elongated, subtrigonal, posterior and anterior un-differenced. Six to eight concentric rows of small endospines in front of the visceral disc. Braquial ridges not observed. Measurements in millimeters and indices in Table 1.

Table 1. Shell dimensions (in millimeters) of Martinezchaconia luisae gen. nov. and sp. nov. with the number of costae per $10 \mathrm{~mm}$ in the anterior margin. Asterisks indicate estimated sizes (incomplete sample).

\begin{tabular}{lcccc}
\hline Specimen & Length & Greatest width & Height & $\begin{array}{l}\text { No. of } \\
\text { costae per } \\
10 \mathrm{~mm}\end{array}$ \\
\hline Ventral valves & & & & \\
FCMP 1201 & 21.2 & 24.4 & $5.5^{*}$ & 14 \\
FCMP 1202 & 18.2 & 21.9 & --- & 13 \\
FCMP 1203 & 14.3 & 17.5 & --- & 14 \\
& & & & \\
Dorsal valves & & & & \\
FCMP 1204 & 13.2 & 16.6 & --- & 16 \\
FCMP 1205 & 16.7 & 18.0 & --- & 14 \\
FCMP 1206 & 18.6 & $22.6 *$ & --- & 12 \\
FCMP 1207 & 13.5 & 13.0 & --- & 15 \\
FCMP 1208 & $19.8 *$ & 23.8 & --- & $13 ?$ \\
FCMP 1209 & 20.4 & 24.0 & --- & $14 ?$ \\
\hline
\end{tabular}

Family Monticuliferidae Muir-Wood \& Cooper, 1960

Subfamily Auriculispininae Waterhouse 1986 (in Waterhouse \& Briggs, 1986)

Tribe Auriculispinini Waterhouse 1986 (in Waterhouse \& Briggs, 1986)

Genus Undaria Muir-Wood \& Cooper, 1960

Type species Undaria manxensis Muir-Wood \& Cooper, 1960 (Balladoole, Isle of Man, Great Britain. Visean).

Undaria sp.
(Fig. 3k)

Occurrence. The specimen described is from Ixtaltepec Formation, Arroyo de las Pulgas type section, level API2, Visean (Middle Mississippian).

Material. A ventral valve (FCMP 1210).

Description. Ventral valve convex, most inflated in posterior region, elongate-oval in outline, tubiform, the greatest width at midlength. Long trail. Narrow corpus cavity. Small and slightly convex ears at angle to visceral disc. Flanks steep and umbo short. The specimen is incomplete with approximately $16 \mathrm{~mm}$ in length and 13 $\mathrm{mm}$ in width. The ornamentation consists of very fine costae, extending from the umbo until the anterior margin, bifurcating at the edge, 18 occurring in a space of $5 \mathrm{~mm}$ over anterior area, absent on ears. Broad, concentric and flexuous rugae on entire valve, rarely bifurcated, occurring 8 in a space of $10 \mathrm{~mm}$ on the middle of the valve. Spines scattered on the trail, as well as clustered on ears.

Remarks. The material of Undaria sp. from Santiago Ixtaltepec displays distinctive traits of the genus such as a small size, large and tubiform trail, complete and prominent costae on concentric rugae, widely scattered spines on the ventral valve and other spines on and near of the hinge (Brunton et al., 2000, p. 545). The specimen is very similar to Undaria manxensis (early Carboniferous = Visean of Great Britain and Belgium) described by Muir-Wood \& Cooper (1960, pl. 118, figs. 4, 13). The elongate-oval ventral valve, ears at right angle to visceral disc, very fine costae which are bifurcated in the anterior margin, occurring about 30 in a space of $10 \mathrm{~mm}$ at midlenght and absent on ears, and spines scattered on ventral valve are features that indicate a similitude between Mexican and European specimens. Nevertheless, due to the presence of clustered spines on ears and the lack of interiors and dorsal valves was not possible to make an accurate specific determination. This is the first record of Undaria in Mexico.

\section{ACKNOWLEDGEMENTS}

The authors thank Gabriela Cisterna for her critical reading and providing valuable suggestions that enriched this work. Also, we thank Erika P. Porras-López for her photographic work and Daniel Navarro-Santillán for his technical assistance.We are very grateful to Elisa Villa and Carmen Álvarez for their invitation to collaborate in this issue dedicated to María Luisa Martínez-Chacón and Luis Sánchez de Posada, very distinguished academics, dear friends and wonderful people. 


\section{REFERENCES}

Abramov, B.S. \& Grigorjeva, A.D. 1988. Biostratigrafiia $i$ Brakhiopody Permi Verkhoian'ia [Permian Biostratigraphy and Brachiopoda of Verkhoyan]. Nauka, Moscow. 204 p. (in Russian).

Brunton, C.H.C., Lazarev, S.S., Grant, R.E. \& Yu-Gan J. 2000. Productidina. In: Treatise on Invertebrate Paleontology, Part H, Brachiopoda, Volume 3 (ed. Kaesler, R.L.). The Geological Society of America, Inc. and The University of Kansas. Boulder, Colorado and Lawrence, Kansas, 424-609.

Carter, J.L. 1968. New genera and species of Early Mississippian brachiopods from the Burlington Limestone. Journal of Paleontology, 42, 1140-1152.

Carter, J.L. 1987. Lower Carboniferous brachiopods from the Banff Formation of western Alberta. Geological Survey of Canada Bulletin, 378, 1-183.

Carter, J.L., Brezinski, D.K., Kollar, A.D. \& Dutro Jr., J.T. 2014. Brachiopoda taxonomy and biostratigraphy of the Redwall Limestone (Lower Mississippian) of Arizona. Annals of Carnegie Museum, 82, 257-290.

Castillo-Espinoza, K. 2013. Sistemática de braquiópodos, cefalópodos y crinoideos del Misisípico Medio de la Formación Santiago, Santiago Ixtaltepec. Oaxaca. Tesis de Maestría, Mexico City, Universidad Nacional Autónoma de México, $119 \mathrm{p}$.

Duméril, A.M.C. 1805. Zoologie Analytique, ou Méthode Naturelle de Classification des Animaux, Rendue plus Facile à l'Aide de Tableaux Synoptiques. Allais, Paris. xxiv $+344 \mathrm{p}$.

Fries, C., Schmitter, E., Damon, P.E. \& Livingstone, D.E. 1962. Rocas precámbricas de edad Grenvilliana de la parte central de Oaxaca en el Sur de México. Boletín del Instituto de Geología, 64, 45-53.

González-Mora, S. \& Sour-Tovar, F. 2014. Briozoarios del Orden Fenestrida, Pensilvánico de la Formación Ixtaltepec, Municipio de Nochixtlán, Oaxaca; consideraciones paleoambientales. Boletín de la Sociedad Geológica Mexicana, 66, 471-482.

Hill, D. 1950. The Productinae of the Artinskian Cracow fauna of Queensland. University of Queensland, Department of Geology, Papers, 3, 1-36.

Landing, E., English, A. \& Keppie, J.D. 2010. Cambrian origin of all skeletalized metazoan phyla-Discovery of Earth's oldest bryozoans (Upper Cambrian, southern Mexico). Geology, 38, 547-550; doi: 10.1130/G30870.1.

Landing, E., Westrop, S.R. \& Keppie, J.D. 2007. Terminal Cambrian and lowest Ordovician succession of Mexican West Gondwana: biotas and sequence stratigraphy of the Tiñú Formation. Geological Magazine, 144, 909-936; doi: 10.1017/S0016756807003585.

Liao, Z. 1979. Uppermost Carboniferous brachiopods from western Guizhou. Acta Palaeontologica Sinica, 18, 227544.

Manankov, I.N. 2008. Mongousia: a new productid genus (Brachiopoda) from the Permian of Northeastern Mongolia. Paleontological Journal, 42, 265-268; doi: 10.1134/ S0031030108030076.
McKellar, R.G. 1970. The Devonian productoid brachiopod faunas of Queensland. Geological Survey of Queensland, Palaeontological Paper, 342, 1-40.

Morón-Ríos, A. \& Perrilliat, M.C. 1988. Una especie nueva del género Griffithides Portlock (Arthropoda, Trilobita) del Paleozoico Superior de Oaxaca. Revista del Instituto de Geología, 7, 67-70.

Muir-Wood, H.M. \& Cooper, G.A. 1960. Morphology, classification and life habits of the Productoidea (Brachiopoda). Geological Society of America, Memoir 81, 1-447; doi: 10.1130/MEM81-p1.

Navarro-Santillán, D., Sour-Tovar, F. \& Centeno-García, E. 2002. Lower Mississippian (Osagean) brachiopods from the Santiago Formation, Oaxaca, Mexico: Stratigraphic and tectonic implications. Journal of South American Earth Sciences, 15, 327-336; doi: 10.1016/S08959811(02)00047-0.

Pantoja-Alor, J. 1970. Rocas sedimentarias paleozoicas de la región centro-septentrional de Oaxaca. In: Libro Guía de la Excursión México-Oaxaca (eds. Segura, L.R. \& RodríguezTorres, R.). Sociedad Geológica Mexicana, 67-84.

Quiroz-Barroso, S.A. \& Perrilliat, M.C. 1997. Pennsylvanian Nuculoids (Bivalvia) from the Ixtaltepec Formation, Oaxaca, Mexico. Journal of Paleontology, 71, 400-407.

Quiroz-Barroso, S.A. \& Perrilliat, M.C. 1998. Pennsylvanian bivalves from the Ixtaltepec Formation, Mexico. Journal of Paleontology, 72, 1011-1024.

Quiroz-Barroso, S.A., Pojeta Jr, J., Sour-Tovar, F. \& MoralesSoto, S. 2000. Pseudomulceodens: A Mississippian Rostroconch from Mexico. Journal of Paleontology, 74, 1184-1186.

Robison, R.A. \& Pantoja-Alor, J. 1968. Tremadocian trilobites from the Nochixtlán region, Oaxaca, Mexico. Journal of Paleontology, 42, 767-800.

Sarytcheva, T.G. \& Sokolskaya, A.V.N. 1959. O klassifikatsin lozhnoporistykh brakhiopod. Akademiia Nauk SSSR, Doklady (Moscow), 125, 181-184.

Shi, G.R., Chen, Z.Q. \& Zhan, L.P. 2005. Early Carboniferous brachiopod faunas from the Baoshan block, west Yunnan, southwest China. Alcheringa, 29, 31-85; doi: 10.1080/03115510508619560.

Solari, L.A., Keppie, J.D., Ortega-Gutiérrez, F., Cameron, K.L., López, R. \& Hames, W.E. 2003. 990 and 1100 Ma Grenvillian tectonothermal events in the northern Oaxacan Complex, southern Mexico: roots of an orogen. Tectonophysics, 365, 257-282; doi: 10.1016/S00401951(03)00025-8.

Sour-Tovar, F., \& Martínez-Chacón, M.L. 2004. Braquiópodos chonetoideos del Carbonífero de México. Revista Española de Paleontología, 19, 125-138.

Stehli, F.G. 1954. Lower Leonardian Brachiopoda of the Sierra Diablo. Bulletin of the American Museum of Natural History, 105, 257-358.

Sutherland, P.K. \& Harlow, F.H. 1973. Pennsylvanian brachiopods and biostratigraphy in southern Sangre de Cristo Mountains, New Mexico. New Mexico Bureau of Mines and Mineral Resources, New Mexico Institute of Mining and Technology, Memoir 27, 173 p. 
Torres-Martínez, M.A. \& Sour-Tovar, F. 2012. Nuevos braquiópodos prodúctidos (Rhynchonelliformea, Strophomenata) del Carbonífero de la región de Nochixtlán, Oaxaca. Revista Mexicana de Ciencias Geológicas, 29, 696-712.

Torres-Martínez, M.A. \& Sour-Tovar, F. 2016a. Braquiópodos discínidos (Lingulida, Discinoidea) de la Formación Ixtaltepec, Carbonífero del área de Santiago Ixtaltepec, Oaxaca. Boletín de la Sociedad Geológica Mexicana, 68, 313-321.

Torres-Martínez, M.A. \& Sour-Tovar, F. 2016b. New Productide Brachiopods (Productoidea) from the Carboniferous of Ixtaltepec Formation, Oaxaca, Mexico. Journal of Paleontology, 90, 418-432.

Torres-Martínez, M.A., Sour-Tovar, F. \& Pérez-Huerta, A. 2008. Neospiriferinid brachiopods (Spiriferida, Trigonotretidae) from Ixtaltepec Formation, Pennsylvanian of Oaxaca State, Southern Mexico. Fossils and Strata, 54, 157-166.

Villanueva-Olea, R. \& Sour-Tovar, F. 2015. A new genus and four new species of cladids (Crinoidea, Cladida) from the Carboniferous of Oaxaca, Southern Mexico. Journal of Systematic Palaeontology, 13, 527-542; doi: 10.1080/14772019.2014.913719.
Villanueva-Olea, R., Castillo-Espinoza, K.M., Sour-Tovar, F., Quiroz-Barroso, S.A. \& Buitrón-Sánchez, B.E. 2011. Placas columnares de crinoides del Carbonífero de la Región de Santiago Ixtaltepec, Municipio de Nochixtlán, Oaxaca; consideraciones estratigráficas y paleobiogeográficas. Boletín de la Sociedad Geológica Mexicana, 63, 429-443.

Waagen, W.H. 1883. Salt range fossils, Vol. 1 Part 4. Productus Limestone fossils, Brachiopoda. Memoirs of the Geological Survey of India, Paleontologia Indica (series 13), 2, 391-546.

Waterhouse, J.B. 1968. New species of Megousia Muir-Wood and Cooper and allied new genus from the Permian of Australia and North America. Journal of Paleontology, 42, 1171-1185.

Waterhouse, J.B. 1975. New Permian and Triassic brachiopod taxa. University of Queensland, Department of Geology Papers, 7, 1-23.

Waterhouse, J.B. \& Briggs, D.J.C. 1986. Late Paleozoic Scyphozoa and Brachiopoda (Inarticulata, Strophomenida, Productida and Rhynchonellida) from the southeast Bowen basin, Australia. Palaeontographica (Abt. A), 193, 1-76.

Williams, A., Carlson, S.J., Brunton, C.H.C., Holmer, L.E. \& Popov, L. 1996. A supra-ordinal classification of the Brachiopoda. Philosophical Transactions of the Royal Society of London, Series B, 351, 1171-1193. 
